\title{
Self-Assembling VHH-Elastin-Like Peptides for Photodynamic Nanomedicine
}

\author{
Jan Pille, ${ }^{\dagger, \ddagger \S}$ Sanne A. M. van Lith, ${ }^{\|, \S}$ Jan C. M. van Hest, ${ }^{*, \dagger},{ }^{\circ}$ and William P. J. Leenders ${ }^{*}, \|_{\odot}$ \\ ${ }^{\dagger}$ Radboud University, Institute for Molecules and Materials, Heyendaalseweg 135, 6525 AJ Nijmegen, The Netherlands \\ ${ }^{*}$ Eindhoven University of Technology, Bio-organic Chemistry Lab, P.O. Box 513 (STO 3.31), 5600 MB Eindhoven, The Netherlands \\ "Department of Pathology, Radboud University Medical Centre, Nijmegen, The Netherlands
}

\section{Supporting Information}

ABSTRACT: Recombinant llama heavy-chain antibody fragments (VHHs) are promising tools in the field of targeted nanomedicine. 7D12, a VHH against the epidermal growth factor receptor (EGFR) that is overexpressed in various cancers, has been evaluated as an effective cancer-targeting VHH in multiple studies. The small size of VHHs $(15-20 \mathrm{kDa})$ results in a low circulation half-life, which can be disadvantageous for certain applications. A solution to this problem is to attach VHHs to the surface of nanoparticles to increase the hydrodynamic radius of the conjugate. This approach simultaneously allows the incorporation of different $\mathrm{VHHs}$ and other targeting moieties and therapeutic components into one structure, creating

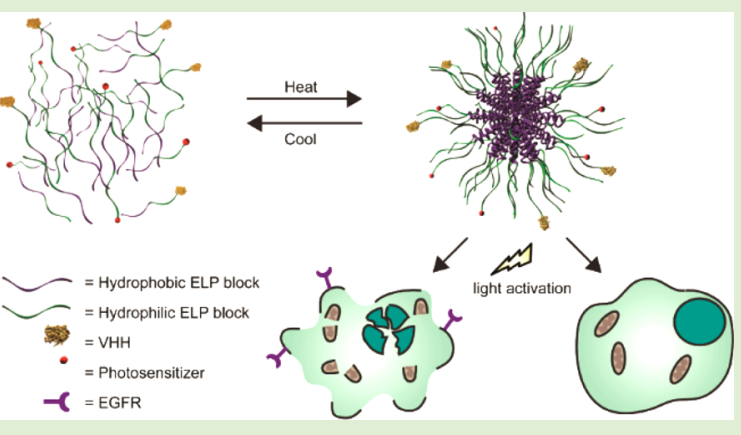
multispecificity and versatility for therapy and diagnosis. Here, we present the construction of highly defined 7D12-containing nanoparticles by utilizing thermoresponsive diblock elastin-like peptides that reversibly self-assemble into micellar structures. The resulting particles have a hydrodynamic radius of $24.3 \pm 0.9$ $\mathrm{nm}$ and retain full EGFR-binding capacity. We present proof of concept of the usability of such particles by controlled incorporation of a photosensitizer and show that the resulting nanoparticles induce EGFR-specific light-induced cell killing. This approach is easily extended to the controlled incorporation of various functional modules, improving therapy and diagnosis with targeted nanomedicine.

\section{INTRODUCTION}

The variable region of heavy-chain antibodies found in cameloids, called $\mathrm{VHH}$, is of great interest to the field of nanomedicine. ${ }^{1-3}$ VHHs are thermo- and $\mathrm{pH}$-stable proteins that are well tolerated by the human immune system. Their affinity can equal or even supersede that of "conventional" antibodies. In combination with cytotoxic agents, tumortargeting VHHs can specifically recognize and kill cancer cells. ${ }^{4,5}$ Although their small size of $15-20 \mathrm{kDa}$ allows deeper tissue penetration than conventional antibodies, it also results in a low circulation half-life.

Nanoparticles decorated with VHHs have been developed to overcome the short blood-circulation time by increasing the hydrodynamic radius; the nanoparticle structure furthermore enables increased and more versatile drug loading. ${ }^{6-8}$ Decoration with VHHs usually follows particle formation, and encapsulation or attachment of a desired payload is typically achieved during particle formation or via an additional coupling step. This procedure makes it difficult to precisely assess and reproducibly control the resulting $\mathrm{VHH}$ concentration on the particles' surface and the VHH-to-payload ratios. Controlling these parameters is essential to achieve maximum efficacy with minimal side effects. Thus, there is a clear need for optimally defined and controlled VHH-displaying nanoparticles.
Elastin-like peptides (ELPs) are biocompatible polypeptides that form amorphous coacervates in a temperature-dependent fashion. ${ }^{9-11}$ They are composed of repeating pentameric units with the sequence glycine-X-glycine-valine-proline (GXGVP), where $\mathrm{X}$ can be any amino acid. ${ }^{11,12}$ ELPs reversibly transform from a soluble, disordered state below the transition temperature to an assembled state consisting of type-II $\beta$-turns, type-I $\beta$-turns, and $\beta$-strands above the transition temperature. ${ }^{13-16}$ This behavior is thermodynamically driven: at the transition temperature, solvation of the protein backbone becomes entropically unfavorable. The conformational change and exposure of hydrophobic residues followed by assembly results in liberated water molecules, lowering the total energy of the system. Further increases in temperature enhance this effect. This so-called lower critical solution temperature (LCST) highly depends on the nature of the guest residue $\mathrm{X}$, with hydrophilic residues raising the LCST and hydrophobic residues lowering it. ELP length, concentration, and presence of salts also affect the LCST. ${ }^{17}$

VHH-ELP fusion proteins have previously been synthesized with the aim to allow easy purification via temperature cycling,

Received: January 13, 2017

Revised: March 3, 2017

Published: March 7, 2017 
followed by $\mathrm{VHH}$ cleavage via introduced protease-sensitive tags. ${ }^{18}$ ELP-based nanoparticles have been prepared out of amphiphilic block copolymers, either by employing ELP diblock polypeptides with different guest residues and, hence, different LCSTs ${ }^{9,10,19}$ or by coupling ELPs with low LCST to hydrophilic polymers such as poly(ethylene glycol). ${ }^{20}$ Given the excellent biocompatible properties of ELPs, ${ }^{21,22}$ we envisioned the possibility of integrating VHH-ELP expression systems with the nanoparticle-forming potential of ELPs.

Here we report the use of an ELP diblock polypeptide $\left(\mathrm{ELP}^{\mathrm{DB}}\right)$ to create self-assembling theranostic VHH-nanoparticles. The $\mathrm{ELP}^{\mathrm{DB}}$ was composed of a "hydrophilic" and a "hydrophobic" block, terms that relate to the solvation state of the ELP block at physiological conditions. The hydrophilic block consisted of 60 pentamers with alanine or glycine guest residues in a ratio of $3: 2$ (see SI). The hydrophobic block contained 60 pentamers with isoleucine as guest residues. We used the VHH 7D12 that targets the epidermal growth factor receptor (EGFR). ${ }^{23,24} \mathrm{Fc5}$, an unrelated $\mathrm{VHH}$ directed against the endothelial receptor Cdc50A, was used as control. ${ }^{25}$ Welldefined composite nanoparticles were reproducibly made by combining $7 \mathrm{D} 12-\mathrm{ELP}^{\mathrm{DB}}$ or $\mathrm{FC} 5-\mathrm{ELP}^{\mathrm{DB}}$ fusion proteins with $\mathrm{ELP}^{\mathrm{DB}}$ as molecularly dissolved species at predetermined ratios, followed by heating the solution above the LCST of the hydrophobic block (Figure 1). The 7D12-decorated ELP

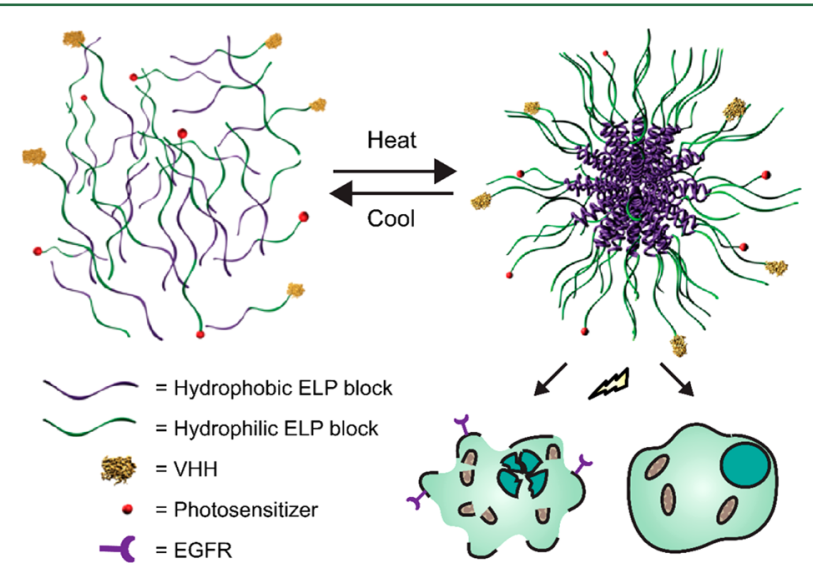

Figure 1. Schematic representation of photodynamic therapy with selfassembling recombinant Llama heavy-chain antibody fragments (VHHs). Amphiphilic diblock elastin-like polypeptides (ELP ${ }^{\mathrm{DB}}$ ) are mixed at low temperatures with $\operatorname{ELP}^{\mathrm{DB}}$ functionalized with a photosensitizer and $\mathrm{ELP}^{\mathrm{DB}}$ functionalized with a VHH directed against epidermal growth factor receptor (EGFR) at a known ratio. Upon heating to $37^{\circ} \mathrm{C}$, components spontaneously assemble into supramolecular structures, simultaneously displaying VHHs and photosensitizer. Only EGFR expressing cells die after incubation with particles and subsequent illumination.

micelles were able to selectively target tumor cells that (over)express EGFR. Upon incorporation of a third $\mathrm{ELP}^{\mathrm{DB}}$ to which the photosensitizer IRDye700DX was conjugated, the composite nanoparticles could be used for highly effective and specific photoimmunotherapy (PIT).

\section{MATERIALS AND METHODS}

All chemicals and consumables were obtained by Sigma-Aldrich, unless specified otherwise.

Cloning and Protein Expression. The VHHs 7D12 and Fc5 were used in this study; 7D12 is directed against EGFR, and Fc5 targets the luminal brain endothelial cell protein Cdc50A. ${ }^{26} 7 \mathrm{D} 12$ and
Fc5 were expressed as fusion products with $\mathrm{ELP}^{\mathrm{DB}}$ and 7D12-CLPETG-HIS-VSV, hereafter, 7D12, was produced as a control for the in vitro studies. The gene sequences encoding for $\mathrm{ELP}^{\mathrm{DB}}$, pelB-Fc5$\mathrm{ELP}^{\mathrm{DB}}$ and pelB-7D12-ELP ${ }^{\mathrm{DB}}$ were cloned into pET-24a $(+)$ (Novagen) expression vectors, ${ }^{27}$ by recursive directional ligation, ${ }^{2}$ transformed into E. coli BLR(DE3) cells and grown on agar plates containing $30 \mu \mathrm{g} / \mathrm{mL}$ kanamycin overnight at $37^{\circ} \mathrm{C}$. A single colony was grown overnight at $30^{\circ} \mathrm{C}, 250 \mathrm{rpm}$ in LB medium containing 50 $\mu \mathrm{g} / \mathrm{mL}$ kanamycin and $0.5 \% \mathrm{w} / \mathrm{v} \mathrm{D}$-glucose. The overnight culture was diluted to an $\mathrm{OD}_{600}$ of 0.1 in filter-sterilized AIM TB medium (Formedium) containing $6 \mathrm{~g} / \mathrm{L}$ glycerol, $0.005 \%$ antifoam 204, and 50 $\mu \mathrm{g} / \mathrm{mL}$ kanamycin. Cells were grown at $300 \mathrm{rpm}$ at $37^{\circ} \mathrm{C}$ for $20 \mathrm{~h}$. For 7D12-ELP ${ }^{\mathrm{DB}}$ and Fc5-ELP ${ }^{\mathrm{DB}}$, the culture was shifted to $30^{\circ} \mathrm{C}$ after $4 \mathrm{~h}$ of growth.

The pHENIX-7D12-C-LPETG-HIS-VSV plasmid was transformed in E. coli strain ER2566. Cells were grown at $37^{\circ} \mathrm{C}$ in $2 \mathrm{xTY}$ medium containing $3.5 \%(\mathrm{w} / \mathrm{v})$ glycerol and $50 \mu \mathrm{g} / \mathrm{mL}$ ampicillin until an $\mathrm{OD}_{600}$ of $0.6-0.8$. Protein expression was induced with $1.0 \mathrm{mM}$ isopropyl $\beta$-D-thiogalactoside (IPTG, Serva, Heidelberg, Germany) at $30{ }^{\circ} \mathrm{C}$ for $2.5 \mathrm{~h}$.

Protein Extraction and Purification. Cells were collected by centrifugation at $2000 \mathrm{~g}, 4^{\circ} \mathrm{C}$ for $30 \mathrm{~min}$. For cytoplasmic extraction, 1 $\mathrm{g}$ of wet cell pellet was resuspended in $2 \mathrm{~mL}$ of lysis buffer $(50 \mathrm{mM}$ Tris- $\mathrm{HCl} \mathrm{pH}$ 8.0, $25 \mathrm{mM} \mathrm{NaCl}, 1 \mathrm{mM}$ EDTA, $0.1 \mathrm{mM}$ PMSF, Complete Protease Inhibitor Cocktail, $0.5 \mathrm{mg} / \mathrm{mL}$ lysozyme) and incubated for $4 \mathrm{~h}$ at $4{ }^{\circ} \mathrm{C}$. Lysis was followed by sonication on a Branson Sonifier 250 (power level 2-4, 12 cycles of $10 \mathrm{~s}$ sonication, $10 \mathrm{~s}$ breaks). Cell debris was collected by centrifugation at 15,000 $\mathrm{g}$ at $4{ }^{\circ} \mathrm{C}$ for $15 \mathrm{~min}$. Residual DNA was precipitated by adding $0.5 \% \mathrm{w} / \mathrm{v}$ poly(ethylene imine) and removed by centrifugation at $15000 \mathrm{~g}$ at 4 ${ }^{\circ} \mathrm{C}$ for $15 \mathrm{~min}$. $\mathrm{ELP}^{\mathrm{DB}}$ was precipitated by adding a saturated solution of $\left(\mathrm{NH}_{4}\right)_{2} \mathrm{SO}_{4}$ up to $10-25 \mathrm{v} / \mathrm{v} \%$. Proteins were collected by centrifugation at $15,000 \mathrm{~g}$ at $4{ }^{\circ} \mathrm{C}$ for $15 \mathrm{~min}$. The pellet was resuspended in phosphate buffered saline and centrifuged to remove insoluble contaminants at $15000 \mathrm{~g}$ at $4{ }^{\circ} \mathrm{C}$ for $20 \mathrm{~min}$. This cycle was repeated until sufficient purity was achieved, usually after $2-4$ cycles. ELPs were resuspended in Milli-Q, desalted on a HiPrep 26/10 (GE Healthcare Life Sciences) with an AKTA Explorer 10 (GE Healthcare Life Sciences) at $1 \mathrm{~mL} / \mathrm{min}$ Milli-Q. Residual salt concentration was below $0.001 \mathrm{mg} / \mathrm{mL}$, as determined by conductivity. The ELP solution was filter-sterilized with $0.22 \mu \mathrm{m}$ PES syringe filters (Nalgene) and freeze-dried. Yield was determined by weighing and varied around 43 $\mathrm{mg} / \mathrm{L}$ culture (Table 1).

For periplasmic extraction of 7D12, 7D12-ELP ${ }^{\mathrm{DB}}$, and Fc5-ELP ${ }^{\mathrm{DB}}, 1$ $\mathrm{g}$ of wet cell pellet was resuspended in $10 \mathrm{~mL}$ of extraction buffer $\mathrm{A}$ (0.2 M TRIS pH 8.0, $0.5 \mathrm{mM}$ EDTA, $20 \mathrm{w} / \mathrm{v} \%$ sucrose, $0.1 \mathrm{mM}$ PMSF, Complete Protease Inhibitor Cocktail) and incubated for 30 $\mathrm{min}$ at $4{ }^{\circ} \mathrm{C}$. Cells were pelleted by centrifugation at $2000 \mathrm{~g}$ for $30 \mathrm{~min}$

Table 1. Overview of Proteins Used in This Study

\begin{tabular}{|c|c|c|c|c|}
\hline construct & $\begin{array}{c}\text { yield }^{a} \\
(\mathrm{mg} / \mathrm{L})\end{array}$ & $\begin{array}{l}\text { theoretical } \\
\text { mass }^{b}(\mathrm{Da})\end{array}$ & $\begin{array}{c}\text { found mass }{ }^{c} \\
\text { (Da) }\end{array}$ & $\begin{array}{c}\text { labeling } \\
\text { efficiency } \\
(\%)\end{array}$ \\
\hline $\mathrm{ELP}^{\mathrm{DB}}$ & 43 & 48198 & 48198 & NA \\
\hline 7D12-ELP ${ }^{\mathrm{DB}}$ & 33 & 63049 & $\begin{array}{c}63031 \text { and } \\
63049\end{array}$ & NA \\
\hline $\mathrm{Fc}_{\mathrm{C} 5}-\mathrm{ELP}^{\mathrm{DB}}$ & 47 & 61903 & 61904 & NA \\
\hline Alexa $^{647}-\mathrm{ELP}^{\mathrm{DB}}$ & NA & 49037 & 49036 & $61 \pm 2$ \\
\hline PS-ELP ${ }^{\mathrm{DB}}$ & NA & 49951 & 49951 & quantitative \\
\hline $7 \mathrm{D} 12^{\mathrm{FL}}-\mathrm{ELP}^{\mathrm{DB}}$ & NA & 63475 & $\begin{array}{c}63457 \text { and } \\
63475\end{array}$ & $89 \pm 12$ \\
\hline $\mathrm{Fc}^{\mathrm{FL}}-\mathrm{ELP}^{\mathrm{DB}}$ & NA & 62330 & 62332 & $88 \pm 3$ \\
\hline
\end{tabular}

${ }^{a}$ Yield specifies obtained product per liter of bacterial culture. ${ }^{b}$ The theoretical mass was determined with ExPASy (http://www.expasy. org/), excluding the $\mathrm{N}$-terminal methionine for $\mathrm{ELP}^{\mathrm{DB}}$ or the pelB sequence for $7 \mathrm{D} 12-\mathrm{ELP}^{\mathrm{DB}}$ and $\mathrm{FC}_{\mathrm{C}}$-ELP ${ }^{\mathrm{DB}}$ (see SI). ${ }^{c}$ Mass found after deconvolution of mass spectrum. ${ }^{d}$ Percentage of labeled protein. 
at $4{ }^{\circ} \mathrm{C}$ and the supernatant collected. The extraction was repeated with extraction buffer $\mathrm{B}\left(0.2 \mathrm{M}\right.$ Tris $\mathrm{pH} 8.0,15 \mathrm{mM} \mathrm{MgSO}_{4}$, Complete Protease Inhibitor Cocktail). Both supernatants were pooled before further processing. ELPs were precipitated as described above. Yield was determined by integration of the absorbance at 280 $\mathrm{nm}$ after separation with a Bio-Sec $5300 \AA$ column on an Agilent BioInert HPLC with a flow rate of $1 \mathrm{~mL} / \mathrm{min}$ PBS (Table 1). Aliquots were flash-frozen in liquid nitrogen and stored at $-80{ }^{\circ} \mathrm{C}$. $7 \mathrm{D} 12$ was purified using Ni-NTA sepharose (IBA, Goettingen, Germany) by incubating the extraction supernatant with pre-equilibrated Ni-NTA sepharose for $1 \mathrm{~h}$ at $4{ }^{\circ} \mathrm{C}$, and after washing, the proteins were eluted with $500 \mathrm{mM}$ imidazole. The eluate was dialyzed against $50 \mathrm{mM}$ Tris$\mathrm{HCl} \mathrm{pH} 7.5$ and $150 \mathrm{mM} \mathrm{NaCl}$.

Sodium Dodecyl Sulfate Polyacrylamide Gel Electrophoresis (SDS-PAGE). Proteins were run under reducing conditions on $12 \%$ SDS-PAGE gels. Gels were either silver-stained in the case of $\mathrm{ELP}^{\mathrm{DB}}$ or stained with coomassie brilliant blue (CBB) in the case of 7D12, $7 \mathrm{D} 12-\mathrm{ELP}^{\mathrm{DB}}$, and FC5-ELP ${ }^{\mathrm{DB}}$. Purity was calculated from integrated pixel intensity after scanning the gels with ImageJ (https://imagej.nih. gov/ij/).

Electrospray lonization-Time-of-Flight Mass Spectrometry (ESI-TOF). Mass was determined by ESI-TOF on a JEOL AccuTOF. Freeze-dried samples were resuspended in Milli- $Q$ to a concentration of $10 \mu \mathrm{M}$, samples containing buffer were first desalted with Milli-Q using Amicon Ultra-0.5 spin filter units (Millipore, $10 \mathrm{kDa}$ MWCO). All samples were acidified with $0.1 \%$ formic acid upon injection. Deconvoluted spectra were obtained using MagTran $1.03 \mathrm{~b} 2$.

Size-Exclusion Chromatography Followed by Multiangle Light Scattering (SEC-MALS). For SEC-MALS, the samples were separated on a Bio-Sec $51000 \AA \AA$ column (Agilent) at $0.4 \mathrm{~mL} / \mathrm{min}$; the mobile phase was $0.1 \mathrm{M}$ phosphate buffer $\mathrm{pH} 7.0$ at $35{ }^{\circ} \mathrm{C}$. 7D12$\mathrm{ELP}^{\mathrm{DB}}$ and FC5-ELP ${ }^{\mathrm{DB}}$ were reduced with TCEP to avoid dimer formation prior to injection for $20 \mathrm{~min}$ at $4{ }^{\circ} \mathrm{C}$. Samples were equilibrated at $35{ }^{\circ} \mathrm{C}$ before injection of $20 \mu \mathrm{L}$. Light scattering data were collected on a DAWN HELEOS II MALS detector (Wyatt) and differential refractive index was measured on an Optilab T-rex refractometer (Wyatt). Dn/dc values were determined theoretically. ${ }^{28}$

Alexa647-ELP ${ }^{D B}$ and PS-ELPDB. Freeze-dried ELPs were resuspended in $50 \mathrm{mM} \mathrm{NaHCO}$ pH 7.84. Alexa647-NHS ester and IRDye 700DX-NHS ester were resuspended in DMSO and added dropwise to the protein solution. The molar ratio $\mathrm{ELP}^{\mathrm{DB}}$ to NHS ester was 1:1 in the case of Alexa 647 and 1:1.3 in the case of IRDye 700DX. The reaction was allowed to proceed for $4 \mathrm{~h}$ at $21{ }^{\circ} \mathrm{C}, 300 \mathrm{rpm}$. Unreacted dye was removed by dialysis against Milli-Q using Amicon Ultra-0.5 spin filter units (Millipore, $10 \mathrm{kDa}$ MWCO). The volume of the dialyzed protein samples was determined; efficiency of conjugation was determined by measuring dye concentration and weighing protein samples after freeze-drying. Concentrations of the dyes were determined at $650 \mathrm{~nm}\left(\varepsilon=270000 \mathrm{~cm}^{-1} \mathrm{M}^{-1}\right)$ and at $689 \mathrm{~nm}(\varepsilon=$ $165000 \mathrm{~cm}^{-1} \mathrm{M}^{-1}$ ) for Alexa647 and IRDye700 DX, respectively. Mass was determined by ESI TOF (Table 1).

7D12 $2^{\mathrm{FL}}$ and $7 \mathrm{D} 12^{\mathrm{PS}}$. Fluorescein-5-maleimide and maleimide$\mathrm{PEG}_{4}$-DBCO (Jena Bioscience, Jena, Germany) were conjugated to 7D12. The free thiol of the C-terminal cysteine in 7D12 was reduced by incubation with $20 \mathrm{mM}$ TCEP for $15 \mathrm{~min}$ at RT. TCEP was removed by dialysis to $20 \mathrm{mM}$ phosphate buffer $\mathrm{pH} 7.0,150 \mathrm{mM}$ $\mathrm{NaCl}$, and $5 \mathrm{mM}$ EDTA in a $10 \mathrm{kDa}$ MWCO centrifugal unit (Amicon, Millipore, Billerica, MS, U.S.A.). The VHH was incubated with either maleimide-5-fluorescein or maleimide- $\mathrm{PEG}_{4}-\mathrm{DBCO}$ in a 1:3 molar ratio for $2 \mathrm{~h}$ at RT. Excess of maleimide probes was removed by dialysis to $50 \mathrm{mM}$ Tris- $\mathrm{HCl} \mathrm{pH} 7.5$ and $150 \mathrm{mM} \mathrm{NaCl}$ in a $10 \mathrm{kDa}$ MWCO centrifugal filter unit. IRDye700DX-NHS ester (LI-COR, Lincoln, NE, U.S.A.) was incubated with $\mathrm{H}_{2} \mathrm{~N}-\mathrm{PEG}_{3}-\mathrm{N}_{3}$ (Jena Bioscience, Jena, Germany) in a 3:1 molar ratio for $7 \mathrm{~h}$ in $100 \mathrm{mM}$ phosphate $\mathrm{pH} 8.6$ and $150 \mathrm{mM} \mathrm{NaCl}$. Subsequently, 7D12 ${ }^{\mathrm{DBCO}}$ was incubated with PS- $\mathrm{N}_{3}$ in a $1: 2$ molar ratio o/n at RT. $7 \mathrm{D} 12^{\mathrm{PS}}$ was purified by filter centrifugation in a $10 \mathrm{kDa}$ MWCO filter unit using 50 $\mathrm{mM}$ Tris- $\mathrm{HCl} \mathrm{pH} 7.5$ and $150 \mathrm{mM} \mathrm{NaCl}$. Protein purity was analyzed with SDS-PAGE gel electrophoresis, and concentration was determined by measuring ultraviolet absorbance at 495 or $689 \mathrm{~nm}$ for FL and PS conjugates, respectively. Aliquots were stored at -80 ${ }^{\circ} \mathrm{C}$.

7D12 $2^{\mathrm{FL}}-\mathrm{ELP}{ }^{\mathrm{DB}}$ and $\mathrm{FC5} 5^{\mathrm{FL}}-\mathrm{ELP} \mathrm{P}^{\mathrm{DB}} \cdot 7 \mathrm{D} 12-\mathrm{ELP}^{\mathrm{DB}}$ and $\mathrm{Fc} 5-\mathrm{ELP}^{\mathrm{DB}}$ were dialyzed to $0.1 \mathrm{M}$ phosphate buffer $\mathrm{pH}$ 7.0. TCEP was added in a ratio of 20:1 to reduce the introduced cysteine. Fluorescein-5maleimide was dissolved in DMSO and added to 7D12-ELP ${ }^{\mathrm{DB}}$ at a ratio of 10:1. Unbound fluorescein-5-maleimide was removed by dialysis using Amicon Ultra-0.5 spin filter units (Millipore, $10 \mathrm{kDa}$ MWCO). Labeling efficiency and protein concentration were determined by integration of the absorbance at 280 and $495 \mathrm{~nm}$ after separation with a Bio-Sec $5300 \AA$ column on an Agilent Bio-Inert HPLC with a flow rate of $1 \mathrm{~mL} / \mathrm{min} 0.1 \mathrm{M} \mathrm{NH}_{4} \mathrm{HCO}_{3} \mathrm{pH} 8.62$ (Table 1). Mass was determined by ESI TOF. $7 \mathrm{D} 12^{\mathrm{FL}}-\mathrm{ELP}^{\mathrm{DB}}$ and $\mathrm{Fc}^{\mathrm{FL}}$ $\mathrm{ELP}^{\mathrm{DB}}$ were flash-frozen in liquid nitrogen and stored at $-80 \mathrm{C}$. See Figure S1 for a fluorescent SDS PAGE analysis.

Dynamic Light Scattering and Stability of ELP Particles in Human Serum. Samples were diluted to a final concentration of 2 $\mu \mathrm{M}$ in PBS. Measurements were performed on a Malvern Zetasizer Nano. Samples were incubated for $5 \mathrm{~min}$ at $37{ }^{\circ} \mathrm{C}$ before data collection. Reported values are averages of three independent measurements. For particle stability, $10 \mu \mathrm{M}$ of $2 \% 7 \mathrm{D} 12^{\mathrm{FL}}-\mathrm{ELP}^{\mathrm{DB}}$, $98 \%$ PS-ELP ${ }^{\mathrm{DB}}$ was added to human serum. Human serum alone, to which an equal volume of PBS alone was added, was taken as control. Light scattering data was collected at 4 and $37{ }^{\circ} \mathrm{C}$. Aggregation was inspected visually. Reported values are averages of three independent measurements.

Cell Culture. Human epidermoid carcinoma A431 cells with amplification of EGFR and high grade astrocytoma E98 cells without EGFR expression were cultured in DMEM (Lonza, Basel, Switzerland), supplemented with 10\% FCS (Gibco) and $40 \mu \mathrm{g} / \mathrm{mL}$ gentamycin (Centrafarm, Etten-Leur, The Netherlands). Cells were cultured at $37{ }^{\circ} \mathrm{C}$ in $5 \% \mathrm{CO}_{2}$ in a humidified atmosphere.

Flow Cytometry. To determine functionality of $7 \mathrm{D} 12^{\mathrm{FL}}-\mathrm{ELP}^{\mathrm{DB}}$ monomers, binding to A431 and E98 cells was determined under noninternalizing conditions at $4{ }^{\circ} \mathrm{C}$. A431 and E98 cells were dissociated from culture flasks using $10 \mathrm{mM}$ EDTA in PBS and transferred to V-bottom shaped 96-well microplates (BD Biosciences, Franklin Lakes, NJ, U.S.A.) at $5 \times 10^{5}$ cells per well. Cells were blocked with PBA (PBS, $0.5 \%$ BSA and $2 \%$ FCS) for 10 min at $4{ }^{\circ} \mathrm{C}$, after which they were incubated with $1 \mu \mathrm{M} 7 \mathrm{D} 12^{\mathrm{FL}}-\mathrm{ELP}^{\mathrm{DB}}$ or controls $\mathrm{Fc}^{\mathrm{FL}}-\mathrm{ELP}^{\mathrm{DB}}$ and $7 \mathrm{D} 12^{\mathrm{FL}}$ in PBA for 30 min at $4{ }^{\circ} \mathrm{C}$. After washing twice with cold PBA, cell-associated fluorescence was quantified on the Cyan flow cytometer (Beckman Coulter, Fullerton, CA, U.S.A.) with parameter FL-1. To determine uptake of VHH functionalized ELP nanoparticles and compare this to monomeric VHHs, A431 and E98 cells were grown to $80 \%$ confluency in 8-well chambered Lab-Tek chambers (NUNC) after which cells were incubated with a concentration range of prewarmed $7 \mathrm{D} 12^{\mathrm{FL}} ; 10 \% 7 \mathrm{D} 12^{\mathrm{FL}}-\mathrm{ELP}^{\mathrm{DB}}, 5 \%$ Alexa647-ELP ${ }^{\mathrm{DB}}, 85 \% \mathrm{ELP}^{\mathrm{DB}}$ particles or $10 \% \mathrm{Fc}^{\mathrm{FL}}-\mathrm{ELP}^{\mathrm{DB}}$, 5\% Alexa647-ELP ${ }^{\mathrm{DB}}, 85 \% \mathrm{ELP}^{\mathrm{DB}}$ particles in DMEM with $10 \% \mathrm{FCS}$ for 30 min at $37{ }^{\circ} \mathrm{C}$. Cells were washed twice with warm DMEM with $10 \%$ FCS, dissociated with trypsin and taken up in PBA, and cell associated fluorescence was quantified on the Cyan flow cytometer with parameters FL-1 and FL-8. Experiments were performed in triplicate and statistical significance was tested with an unpaired Student's $t$ test. Furthermore, cells were imaged after incubation with $\operatorname{ELP}^{\mathrm{DB}}$ particles (or equimolar VHH of $7 \mathrm{D} 12^{\mathrm{FL}}$ ) on the EVOS microscope using LED cubes GFP (Fluorescein) and Cy5 (Alexa647).

In Vitro PDT Assays. A431 and E98 cells were cultured in clear 96 wells plates until $80 \%$ confluency. Then cells were incubated with a concentration range of prewarmed $7 \mathrm{D} 12^{\mathrm{PS}}$ or $2 \% 7 \mathrm{D} 12^{\mathrm{FL}}-\mathrm{ELP}^{\mathrm{DB}}, 98 \%$ PS-ELP ${ }^{\mathrm{DB}}$ particles or $2 \% \mathrm{Fc5}^{\mathrm{FL}}$-ELP ${ }^{\mathrm{DB}}, 98 \%$ PS-ELP ${ }^{\mathrm{DB}}$ particles in DMEM with $10 \%$ FCS for $30 \mathrm{~min}$ at $37^{\circ} \mathrm{C}$. Cells were washed twice with warm DMEM with $10 \%$ FCS, and subsequently, cells were illuminated with $100 \mathrm{~mW} / \mathrm{cm}^{2}$ for $600 \mathrm{~s}$, reaching a total light dose of $60 \mathrm{~J} / \mathrm{m}^{2}$, using a standardized light emitting diode device $(690 \pm 10$ $\mathrm{nm})$. Cells were incubated with $729 \mathrm{nM}$ of $10 \% 7 \mathrm{D} 12-\mathrm{ELP}^{\mathrm{DB}}, 10 \%$ PS$\mathrm{ELP}^{\mathrm{DB}}, 10 \% \mathrm{Fc} 5-\mathrm{ELP}^{\mathrm{DB}}, 10 \%$ PS-ELP ${ }^{\mathrm{DB}}$ particles, or $72.9 \mathrm{nM} 7 \mathrm{D} 12^{\mathrm{PS}}$ without subsequent illumination to determine dark toxicity. Cell viability was quantified using sulforhodamine B (SRB) colorimetric 
A

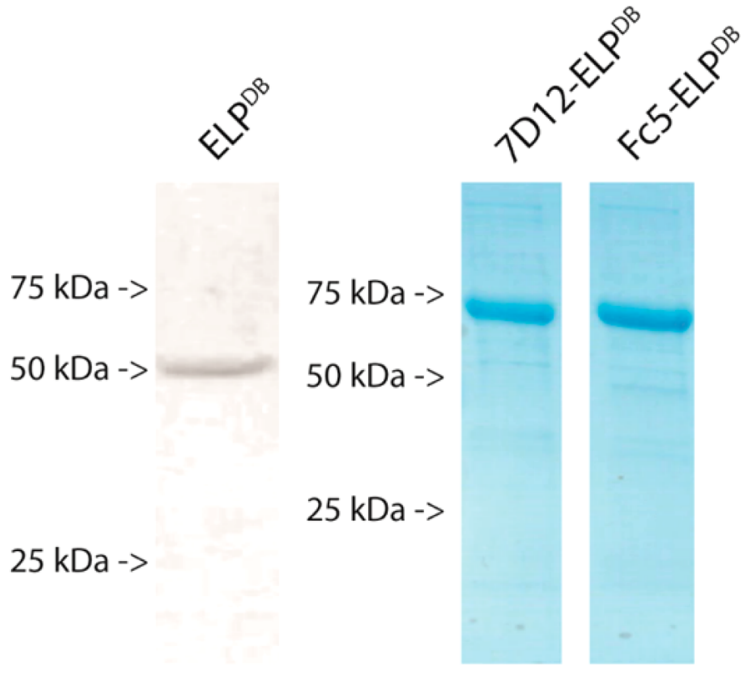

C

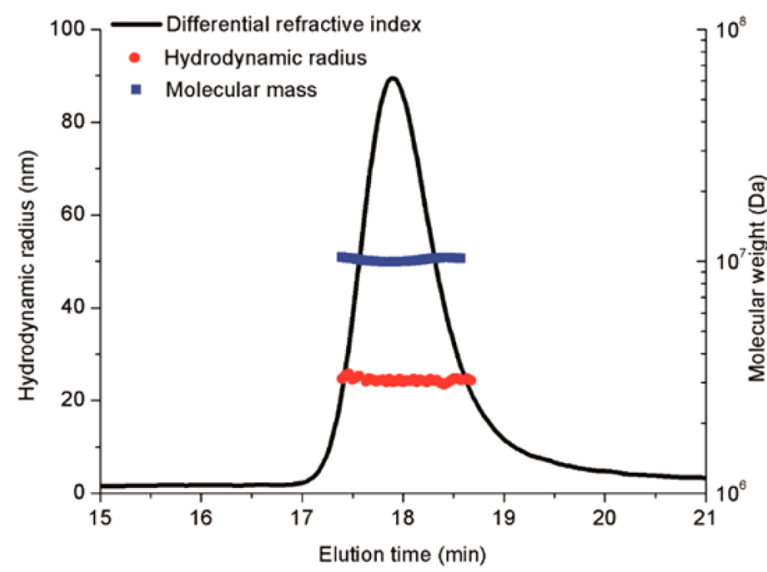

B

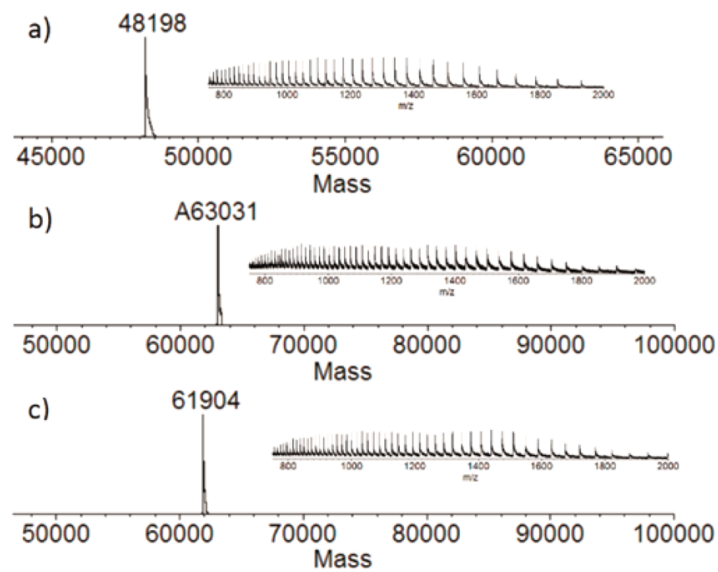

D

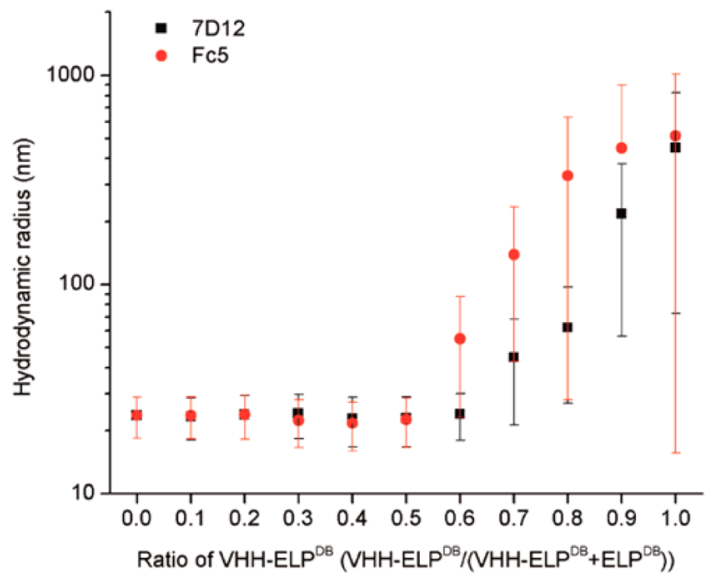

Figure 2. Characterization of expressed proteins and formed nanoparticles: (A) SDS-PAGE of ELP ${ }^{\mathrm{DB}}$ (silver-stained, absence of aromatic amino acids in the ELP prevents Coomassie Brilliant Blue (CBB) staining), 7D12-ELP ${ }^{\mathrm{DB}}$, and Fc5-ELP ${ }^{\mathrm{DB}}$ (stained with CBB). (B) Mass spectra and deconvoluted masses of (a) $\mathrm{ELP}^{\mathrm{DB}}$, (b) 7D12-ELP ${ }^{\mathrm{DB}}$, and (c) Fc5-ELP ${ }^{\mathrm{DB}}$. (C) Size-exclusion chromatography coupled to multiangle light scattering of nanoparticles containing 10\% 7D12-ELP ${ }^{\mathrm{DB}}$. (D) Evaluation of nanoparticle stability as a function of the fraction of $7 \mathrm{D} 12-\mathrm{ELP}^{\mathrm{DB}}$ or Fc5-ELP ${ }^{\mathrm{DB}} \cdot X^{-}$ axis represents the ratio of $\mathrm{VHH}-\mathrm{ELP}^{\mathrm{DB}}$ to $\mathrm{ELP}^{\mathrm{DB}}$ in the micelles.

assays, and results were expressed as cell viability relative to untreated illuminated cells.

To examine selectivity of PDT-induced cytotoxicity, $5 \times 10^{5}$ cells were labeled with DiO (A431) or DID (E98) dye (Life Technologies, Thermo Fisher Scientific, Waltham, MA, U.S.A.) according to manufacturers' protocol. A431, E98, or 1:1 mixtures of the cells were plated and subjected to PIT with $30 \mathrm{nM}$ of the particles or equimolar $\mathrm{VHH}$ concentrations of the $7 \mathrm{D} 12^{\mathrm{PS}}$ control as described above. Four hours after illumination, cells were incubated with $1 \mu \mathrm{g} /$ $\mathrm{mL}$ propidium iodide (Thermo Fisher Scientific, Waltham, MA, U.S.A.) in PBS for $15 \mathrm{~min}$. Cells were visualized with the EVOS microscope using the RFP channel (propidium iodide), the GFP channel (DiO-labeled cells), and the Cy5 channel (DiD-labeled cells).

Stability of ELP ${ }^{D B}$ Particles in Human Serum. Stability of $\mathrm{ELP}^{\mathrm{DB}}$ particles in serum was evaluated further by incubating $96 \mathrm{nM}$ [ELP] $2 \% 7 \mathrm{D} 12^{\mathrm{FL}}-\mathrm{ELP}^{\mathrm{DB}}, 98 \% \mathrm{PS}-\mathrm{ELP}^{\mathrm{DB}}$ or $2 \% \mathrm{Fc} 5^{\mathrm{FL}}-\mathrm{ELP}^{\mathrm{DB}}, 98 \%$ PS-ELP ${ }^{\mathrm{DB}}$ in freshly obtained human serum (HS) for either $30 \mathrm{~min}, 2$ $\mathrm{h}$, or $4 \mathrm{~h}$ at $37^{\circ} \mathrm{C}$. Subsequently, the $96 \mathrm{nM}$ stocks were diluted in DMEM with $10 \%$ FCS, and PDT assays were performed with A431 cells as described earlier. Cell viability was compared to controls incubated with diluted serum without PS-ELP ${ }^{\mathrm{DB}}$ micelles and with PS$\mathrm{ELP}^{\mathrm{DB}}$ micelles directly diluted in DMEM with $10 \%$ FCS.

\section{RESULTS AND DISCUSSION}

VHH-ELP ${ }^{\mathrm{DB}} \mathrm{s}$ were prepared by cloning cDNA sequences coding for $7 \mathrm{D} 12$ and $\mathrm{Fc5}$ in frame with $\mathrm{ELP}^{\mathrm{DB}}$. An intervening cysteine residue was introduced as a handle for maleimidebased modification. Fusion proteins were successfully expressed in BLR(DE3) Escherichia coli cells by autoinduction (Figure 2). The sequences were preceded by a pelB leader sequence to direct the protein to the periplasm of E. coli. The slightly oxidative milieu in the bacterial periplasm allowed the proper formation of internal disulfide bonds present in 7D12 and Fc5. The proteins were purified by inverse-transition cycling. ELP ${ }^{\mathrm{DB}}$ and $\mathrm{VHH}-E L \mathrm{P}^{\mathrm{DB}}$ fusion proteins were obtained in $>95 \%$ purity with $20-50 \mathrm{mg} / \mathrm{L}$ yield (Table 1, Figure 2A). Molecular masses of the protein samples were measured via electrospray ionization time-of-flight spectrometry (ESI-ToF) and agreed well with the predicted masses (Figure 2B). The N-terminal formyl methionine of $\mathrm{ELP}^{\mathrm{DB}}$ was cleaved off as expected. ${ }^{29}$ For $7 \mathrm{D} 12-\mathrm{ELP}^{\mathrm{DB}}$ and $\mathrm{Fc5}-\mathrm{ELP}^{\mathrm{DB}}$, complete removal of the pelB sequence was observed. For $7 \mathrm{D} 12-\mathrm{ELP}^{\mathrm{DB}}$, an additional peak was found. 7D12 contains an N-terminal glutamine, which is known to be converted in an autocatalytic or enzymatic step to 
Table 2. Results from SEC-MALS Measurements of the Different Nanoparticle Formulations

\begin{tabular}{lcccc}
\multicolumn{1}{c}{ sample } & $R_{\mathrm{h}^{a}}(\mathrm{~nm})$ & $R_{\mathrm{rms}}{ }^{b}(\mathrm{~nm})$ & $\rho^{c}$ & mass $^{d}(\mathrm{kDa})$ \\
$\mathrm{ELP}^{\mathrm{DB}}$ & $24.0 \pm 0.5$ & $17.2 \pm 0.1$ & $0.72 \pm 0.02$ & $10300 \pm 15$ \\
$10 \% 7 \mathrm{D} 12-\mathrm{ELP}^{\mathrm{DB}}$ & $24.6 \pm 0.6$ & $17.4 \pm 0.1$ & $0.71 \pm 0.02$ & $9958 \pm 17$ \\
$10 \%$ Fc5-ELP & & & 214 \\
& $24.3 \pm 0.6$ & $19.8 \pm 0.3$ & $0.81 \pm 0.02$ & $10470 \pm 16$
\end{tabular}

${ }^{a}$ Hydrodynamic radius. ${ }^{b}$ Radius of gyration. ${ }^{c}$ Radius of gyration divided by the hydrodynamic radius. ${ }^{d}$ Average molecular mass. ${ }^{e}$ Monomers per micelle calculated with the weighted average molecular mass of $\mathrm{ELP}^{\mathrm{DB}}$ particles and monomers. See Figure S3 for SEC-MALS data.

A

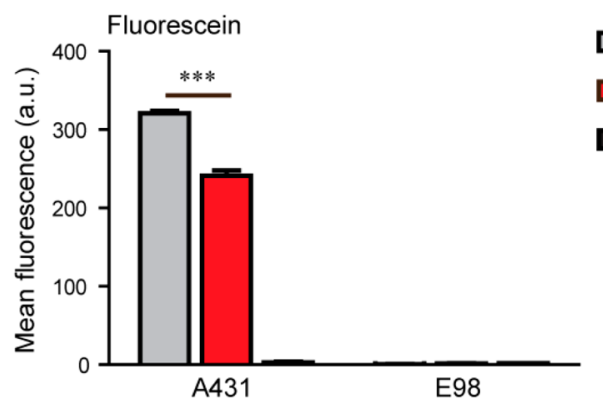

B
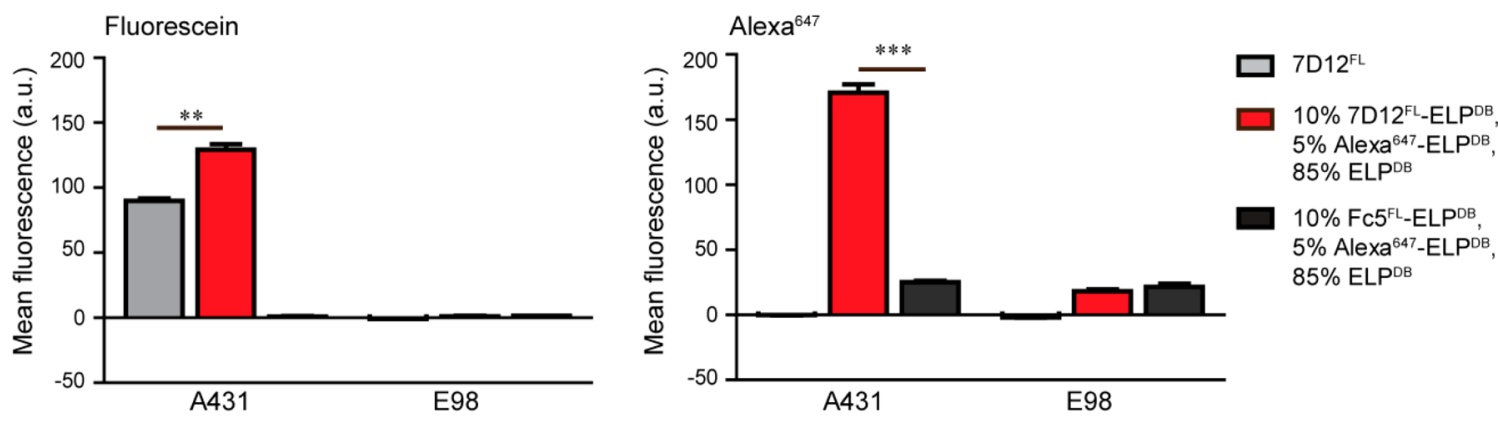

C
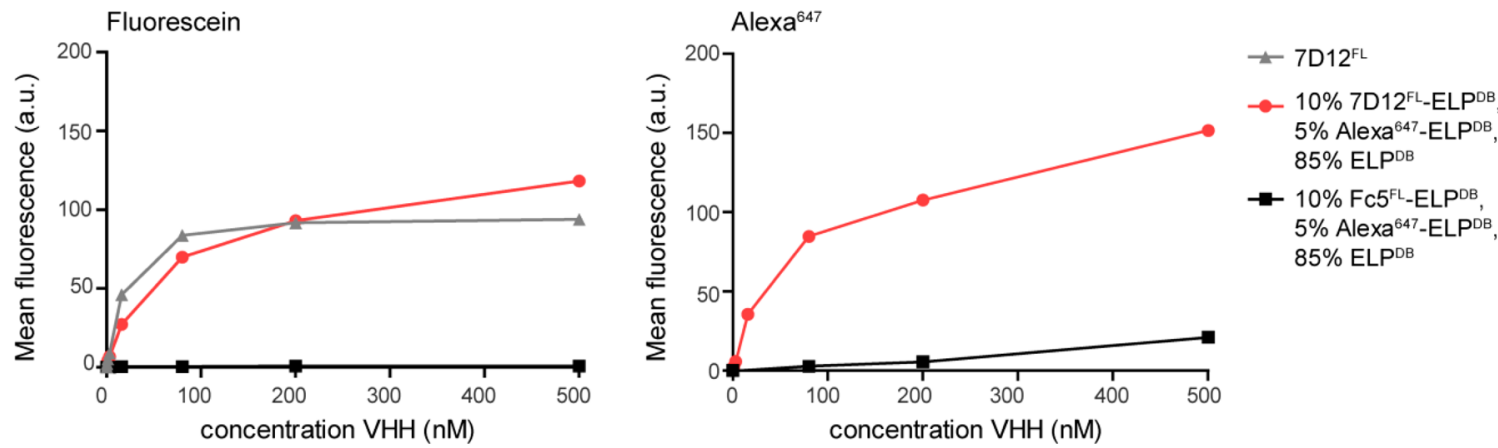

Figure 3. Cellular binding and uptake of $\mathrm{VHH}^{\mathrm{FL}}-\mathrm{ELP}^{\mathrm{DB}}$ monomers and micelles, respectively. (A) Cell-associated FL fluorescence as determined with flow cytometry after cold $\left(4{ }^{\circ} \mathrm{C}\right)$ incubation with $1 \mu \mathrm{M} 7 \mathrm{D} 12^{\mathrm{FL}}, 7 \mathrm{D} 12^{\mathrm{FL}}-\mathrm{ELP}^{\mathrm{DB}}$, or $\mathrm{Fc} 5^{\mathrm{FL}}-\mathrm{ELP} \mathrm{PB}^{\mathrm{DB}}$ monomers. (B) Cell-associated $\mathrm{FL}$ and Alexa647 fluorescence, as determined with flow cytometry after warm $\left(37^{\circ} \mathrm{C}\right.$ ) incubation with $10 \mu \mathrm{M}$ (refers to total $\mathrm{ELP}^{\mathrm{DB}}$ concentration) of $7 \mathrm{D} 12^{\mathrm{FL}}$-Alexa647-ELP ${ }^{\mathrm{DB}}$ micelles or $\mathrm{Fc} 5^{\mathrm{FL}}$-Alexa647-ELP ${ }^{\mathrm{DB}}$ micelles. Note that there is some unexplained nonspecific background binding of Alexa$\mathrm{ELP}^{\mathrm{DB}}$, but not of $\mathrm{VHH}^{\mathrm{FL}}$-ELP ${ }^{\mathrm{DB}}$. (C) Cell-associated $\mathrm{FL}$ and Alexa647 fluorescence as determined with flow cytometry after warm $\left(37{ }^{\circ} \mathrm{C}\right)$ incubation of A431 cells with a concentration range of $7 \mathrm{D} 12^{\mathrm{FL}}$-Alexa647-ELP ${ }^{\mathrm{DB}}$ micelles or $\mathrm{Fc} 5^{\mathrm{FL}}$-Alexa647-ELP ${ }^{\mathrm{DB}}$ micelles. ${ }^{*}$ indicates significance with $p<0.05, * *$ indicates significance with $p<0.01$, *** indicates significance with $p<0.001$.

pyroglutamate, resulting in the loss of ammonia, explaining the 18 Da difference. ${ }^{30}$ FC5-ELP $^{\mathrm{DB}}$, which does not contain $\mathrm{N}$ terminal glutamine, did not show this side product (Table 1).

$\mathrm{ELP}^{\mathrm{DB}}$ nanoparticles were stable between 25 and $55{ }^{\circ} \mathrm{C}$ (Figure S2). For characterization, purified $\mathrm{ELP}^{\mathrm{DB}}$ was heated to $37^{\circ} \mathrm{C}$ after which hydrodynamic radius, radius of gyration, and molecular weight were determined by size-exclusion chromatography, followed by multiangle light scattering (Figures 2C and S3). The hydrodynamic radius was approximately $24 \mathrm{~nm}$ (Table 2). The ratio of radius of gyration to hydrodynamic radius, an indication of the morphology of particles, was close to the theoretical value of a homogeneous sphere $(0.778){ }^{31,32}$ The mass distribution (with an average of $10.3 \mathrm{MDa}$ ) revealed that particles consisted of on average 214 monomers per micelle, in agreement with comparable ELP particles. ${ }^{11}$ 
A
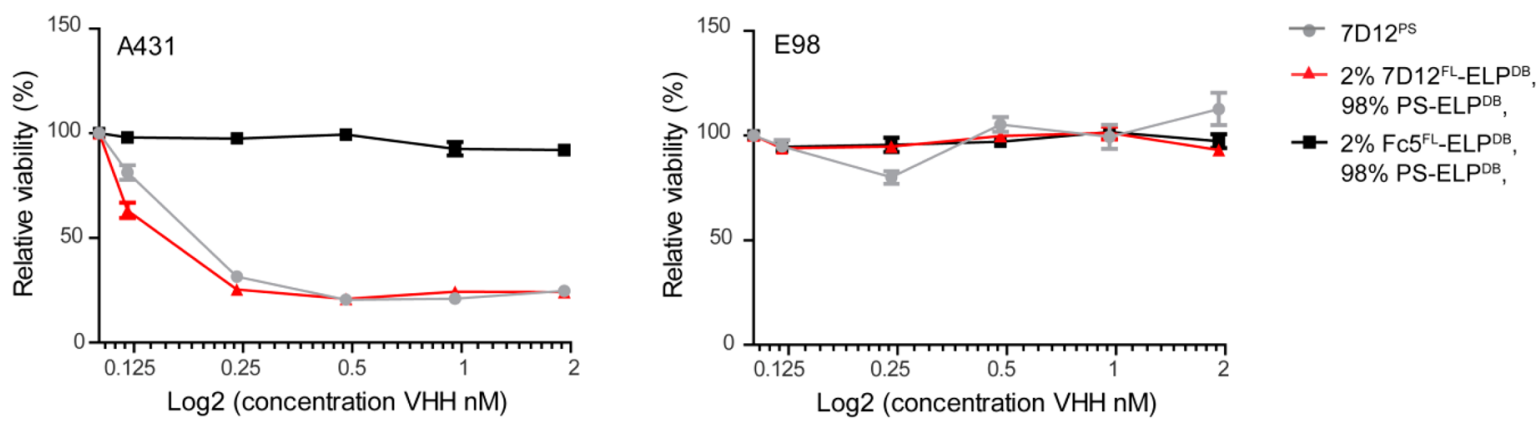

B

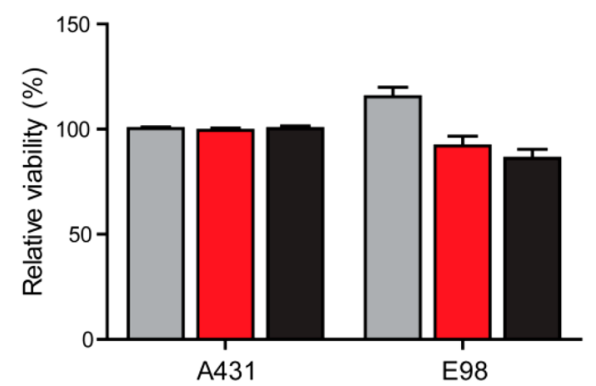

$7 \mathrm{D} 12^{\mathrm{PS}}$

$10 \% 7 \mathrm{D} 12^{\mathrm{FL}}$-ELP ${ }^{\mathrm{DB}}$ $10 \%$ PS-ELPDB $80 \%$ ELPDB

$10 \% \mathrm{FC5}^{\mathrm{FL}}$-ELPDB, $10 \%$ PS-ELPDB, $80 \%$ ELP $^{\mathrm{DB}}$

C
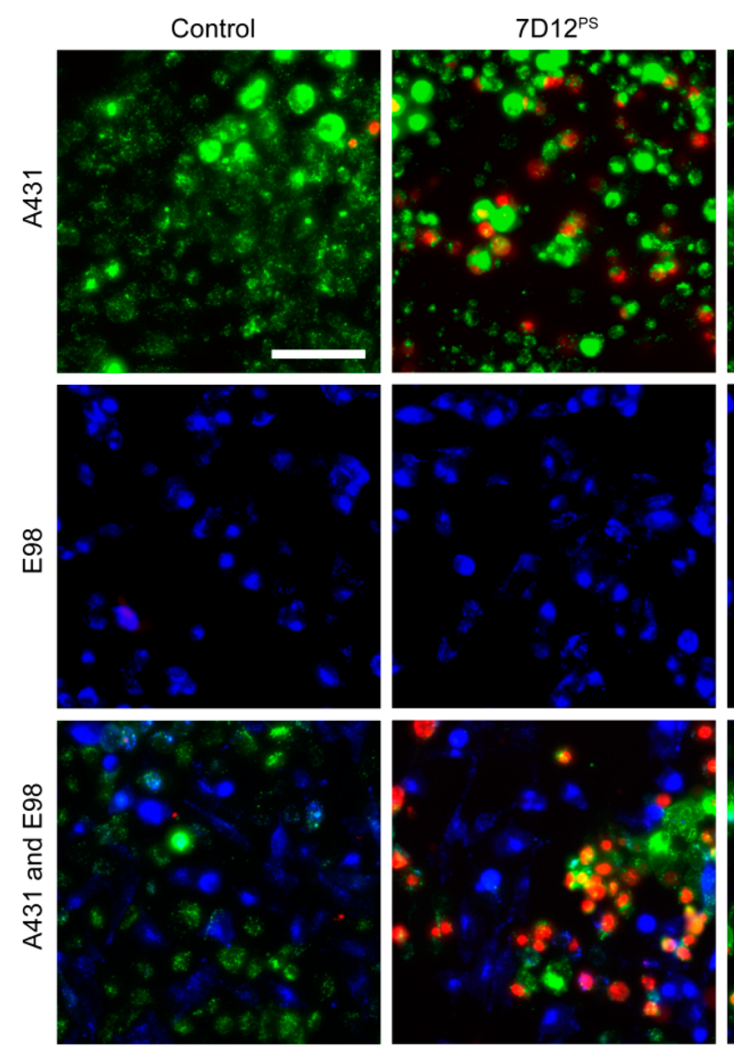

7D12 ${ }^{\mathrm{PS}}$
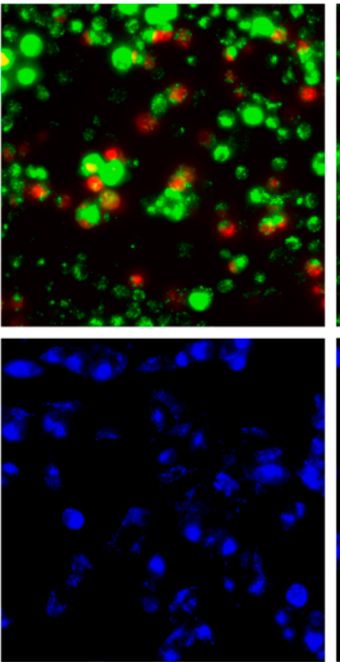

2\% 7D12 $12^{\text {FL-ELPDB }}$ $98 \%$ PS-ELPDB
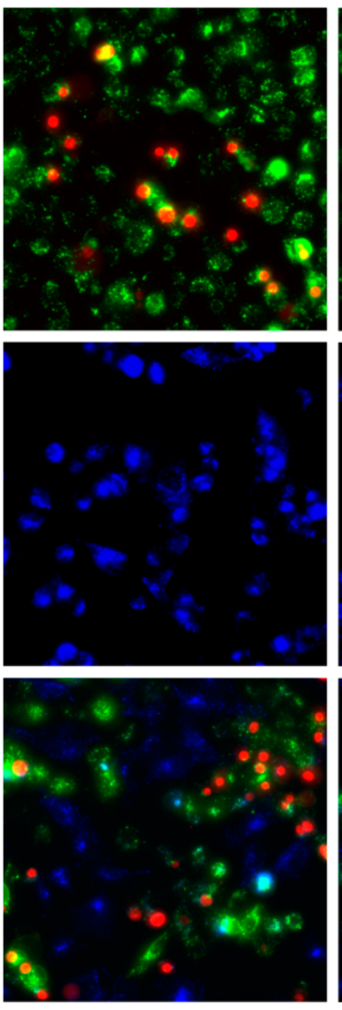

$2 \% \mathrm{FC}^{\mathrm{FL}}$-ELP ${ }^{\mathrm{DB}}$, $98 \%$ PS-ELPDB
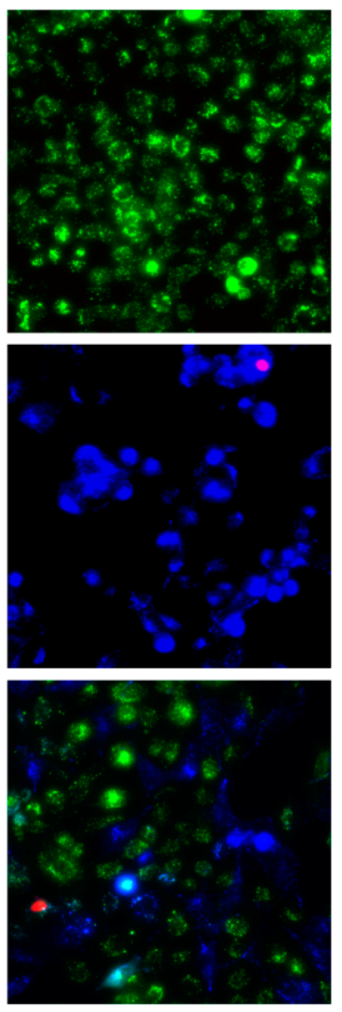

Propidium lodide E98 A431

Figure 4. Phototoxicity induced by $\mathrm{VHH}^{\mathrm{FL}}$-PS-ELP ${ }^{\mathrm{DB}}$ micelles in $\mathrm{A} 431$ and $\mathrm{E} 98$ cells. (A) Relative cell viability after incubation and illumination with either $7 \mathrm{D} 12^{\mathrm{FL}}-\mathrm{PS}-\mathrm{ELP} \mathrm{P}^{\mathrm{DB}}$ micelles, $\mathrm{Fc} 5^{\mathrm{FL}}-\mathrm{PS}-\mathrm{ELP} \mathrm{P}^{\mathrm{DB}}$ micelles, or $7 \mathrm{D} 12^{\mathrm{PS}}$ control. (B) Relative cell viability after incubation without illumination with either $7 \mathrm{D} 12^{\mathrm{FL}}-\mathrm{PS}-\mathrm{ELP} \mathrm{P}^{\mathrm{DB}}$ micelles or $\mathrm{Fc} 5^{\mathrm{FL}}$-PS-ELP ${ }^{\mathrm{DB}}$ micelles or $7 \mathrm{D} 12^{\mathrm{PS}}$ control. Note the absence of dark toxicity. (C) Fluorescence microscopy of DiD-labeled A431 (green) and DiO-labeled E98 (blue) (co)cultures that are incubated with propidium iodide (red) after incubation with $30 \mathrm{nM} 7 \mathrm{D} 12-\mathrm{ELP}^{\mathrm{DB}}$ or Fc5-ELP ${ }^{\mathrm{DB}}$ based PS-ELP ${ }^{\mathrm{DB}}$ particles or equimolar VHH $7 \mathrm{D} 12^{\mathrm{PS}}$ and illumination. The scale bar denotes $100 \mu \mathrm{m}$.

In order to determine the maximum possible functionalization degree of the nanoparticles with $\mathrm{VHH}$, we proceeded by systematically mixing $\mathrm{ELP}^{\mathrm{DB}}$ with different percentages of $7 \mathrm{D} 12-\mathrm{ELP}^{\mathrm{DB}}$ or $\mathrm{Fc} 5-\mathrm{ELP}^{\mathrm{DB}}$. We observed a transition point at 
$50 \% 7 \mathrm{D} 12 \mathrm{FL}-\mathrm{ELP}^{\mathrm{DB}}$ and $60 \%$ Fc5FL-ELP ${ }^{\mathrm{DB}}$, respectively. Above this ratio, uncontrolled aggregation resulted in micrometer-sized aggregates or coacervates (Figure 2D). The loss of particle stability can be explained by a geometrical model. Assuming a homogeneous sphere with a radius of $24 \mathrm{~nm}$, consisting of 214 monomers, each exposed monomer terminus occupies a surface of $33.8 \mathrm{~nm}^{2}$ or a sphere with a radius of approximately $2 \mathrm{~nm}$. Since the radius of $\mathrm{VHHs}$ is around 2-3 $\mathrm{nm},{ }^{33}$ it is highly plausible that steric hindrance at high $\mathrm{VHH}-$ $\mathrm{ELP}^{\mathrm{DB}}$ ratios occurs, leading to rearrangement and/or aggregation.

Incorporation of $10 \% \mathrm{VHH}-\mathrm{ELP}^{\mathrm{DB}}$ resulted in well-defined micelles with physicochemical characteristics similar to $\mathrm{ELP}^{\mathrm{DB}}$ micelles (Table 2, Figures 2C and S3). This percentage should result in a display of approximately $20 \mathrm{VHH}$ molecules per micelle.

Since the LCST of ELP ${ }^{\mathrm{DB}}$ is concentration dependent, we determined the critical micelle concentration (CMC) by dynamic light scattering (DLS) and found that the CMC is lower than $100 \mathrm{nM}$ (Figure S4).

In order to mimic in vivo conditions we investigated the effect of the presence of human serum (HS) on the particle properties. ELP micelles in HS were shown to be stable for at least $2 \mathrm{~h}$ at $37{ }^{\circ} \mathrm{C}$ and, furthermore, could be reversibly assembled in a temperature-dependent manner (Figure S5).

To separately follow the fate of VHH-ELP ${ }^{\mathrm{DB}}$ and $\mathrm{ELP}^{\mathrm{DB}}$ after cellular uptake of composite micelles, we labeled VHH-ELP $\mathrm{PB}^{\mathrm{B}}$ with fluorescein-5-maleimide (FL), yielding $7 \mathrm{D} 12^{\mathrm{FL}}-\mathrm{ELP}^{\mathrm{DB}}$ and $\mathrm{Fc}^{\mathrm{FL}}$-ELP $\mathrm{PB}^{\mathrm{DB}}$. ELP $\mathrm{EPB}^{\mathrm{DB}}$ was labeled with Alexa647-N-hydroxysuccinimide (NHS) ester or IRDye700DX (PS) via NHS chemistry at the $\mathrm{N}$-terminal amino group of $\mathrm{ELP}^{\mathrm{DB}}$, yielding Alexa647-ELP ${ }^{\mathrm{DB}}$ and PS-ELP ${ }^{\mathrm{DB}}$, respectively (Table 1, Figure S6).

FL-fluorescence-based flow cytometry, performed at $4{ }^{\circ} \mathrm{C}$ to prevent self-assembly into micelles and internalization, showed that monomeric $7 \mathrm{D} 12^{\mathrm{FL}}-\mathrm{ELP}^{\mathrm{DB}}$, but not $\mathrm{Fc}^{\mathrm{FL}}-\mathrm{ELP}^{\mathrm{DB}}$, effectively bound to EGFR-expressing A431 cells (Figure 3A), demonstrating that the 7D12 moiety had retained its EGFR affinity. $7 \mathrm{D} 12^{\mathrm{FL}}-\mathrm{ELP}^{\mathrm{DB}}$ binding was slightly less than the $7 \mathrm{D} 12^{\mathrm{FL}}$ control, indicating that the fusion to $\mathrm{ELP}^{\mathrm{DB}}$ may induce some steric hindrance at low temperatures. No binding to the EGFR-negative E98 cell line was observed for either $7 \mathrm{D} 12^{\mathrm{FL}}$ $\mathrm{ELP}^{\mathrm{DB}}$ or $\mathrm{Fc}^{\mathrm{FL}}-\mathrm{ELP}^{\mathrm{DB}}$. These experiments clearly illustrate that the specificity of 7D12 remains unchanged in the context of a fusion protein with $\mathrm{ELP}^{\mathrm{DB}}$, and that $\mathrm{ELP}^{\mathrm{DB}}$ itself did not show aspecific binding to the cell lines tested.

We next prepared micelles by heating a mixture of $\mathrm{ELP}^{\mathrm{DB}}$, Alexa647-ELP ${ }^{\mathrm{DB}}$, and $\mathrm{VHH}^{\mathrm{FL}}-\mathrm{ELP}^{\mathrm{DB}}(85: 5: 10)$ to $37^{\circ} \mathrm{C}$ and analyzed in vitro binding and uptake by measuring cellassociated FL fluorescence and Alexa647 fluorescence in flow cytometry experiments. $7 \mathrm{D} 12^{\mathrm{FL}}$-Alexa647-ELP ${ }^{\mathrm{DB}}$ micelles associated with A431 cells but not with EGFR-negative E98 cells (Figure 3B).

Incubation with composite $7 \mathrm{D} 12^{\mathrm{FL}}$-Alexa647-ELP ${ }^{\mathrm{DB}}$ micelles resulted in $44 \%$ higher cell-associated FL fluorescence relative to the situation in which equal concentrations of (monomeric) $7 \mathrm{D} 12^{\mathrm{FL}}$ were used, indicating a multivalency and avidity effect of $7 \mathrm{D} 12^{\mathrm{FL}}$ induced by particle formation. Of note, incubation of A431 with $7 \mathrm{D} 12^{\mathrm{FL}}$-Alexa647-ELP ${ }^{\mathrm{DB}}$ micelles also resulted in cell-associated Alexa647 fluorescence (Figure 3B), and fluorescence microscopy revealed membranous and intracellular colocalization of both Alexa647 and FL (Figure S7), indicating that $7 \mathrm{D} 12^{\mathrm{FL}}$ associated with the cells as part of intact micelles. Fc5 $5^{\mathrm{FL}}$-Alexa647-ELP ${ }^{\mathrm{DB}}$ micelles showed little background association with A431 cells. Altogether, these data show that composite $7 \mathrm{D} 12^{\mathrm{FL}}$-Alexa647-ELP ${ }^{\mathrm{DB}}$ micelles that target tumor cells in an EGFR-specific manner can be created.

Unfortunately, 7D12 binds to EGFR only in a cell context. ${ }^{34}$ Since the VHH is internalized upon EGFR binding at $37{ }^{\circ} \mathrm{C}$, it is difficult to quantitatively compare avidity effects of $7 \mathrm{D} 12^{\mathrm{FL}}$ in micellar or monomeric form, because at $37{ }^{\circ} \mathrm{C}$ results will always be biased by internalization effects. Future studies with other VHH-ELP constructs that can be used in cell-free systems may provide important answers on the subject of avidity.

In an effort to determine the CMC of the functionalized particles in vitro, we varied the concentration of all components, maintaining the same ratios. As shown in Figure 3C, 7D12-induced binding and uptake of Alexa647-ELP ${ }^{\mathrm{DB}}$ occurred at concentrations as low as $160 \mathrm{nM}$ (VHH concentration of $16 \mathrm{nM}$ ), showing the presence of cofunctionalized micelles and agreeing with results obtained by DLS. Using lower $\mathrm{ELP}^{\mathrm{DB}}$ concentrations for more accurate determination of the CMC was not feasible due to insufficient fluorophore signal-to-noise ratio. For a more accurate determination in vitro, we used the photodynamic therapy assay as described below.

To test whether EGFR-targeting $\mathrm{ELP}^{\mathrm{DB}}$-based micelles can be used in a therapeutic manner, we prepared $7 \mathrm{D} 12^{\mathrm{FL}}-\mathrm{ELP} \mathrm{P}^{\mathrm{DB}}$ micelles containing the photosensitizer IRDye700DX, conjugated to $\mathrm{ELP}^{\mathrm{DB}}$ (PS-ELP ${ }^{\mathrm{DB}}$ ). To achieve maximum drug loading while maintaining sufficient targeting capacity, we prepared micelles containing $2 \% \mathrm{VHH}^{\mathrm{FL}}-\mathrm{ELP}^{\mathrm{DB}}$ and $98 \%$ PS$\mathrm{ELP}^{\mathrm{DB}}$. Cell-killing efficiency of these micelles was compared to cell killing by monomeric 7D12, directly conjugated with IRDye700DX $\left(7 \mathrm{D} 12^{\mathrm{PS}}\right)$. A431 or E98 cells were incubated with $7 \mathrm{D} 12^{\mathrm{FL}}$-PS-micelles or equimolar amounts of $7 \mathrm{D} 12^{\mathrm{PS}}$ prior to illumination. $7 \mathrm{D} 12^{\mathrm{FL}}-\mathrm{PS}-\mathrm{ELP}^{\mathrm{DB}}$ micelles actively killed A431 cells in a light-dependent and 7D12-specific manner with an $\mathrm{EC}_{50}$ concentration of $82.7 \mathrm{pM}$ compared to $121.5 \mathrm{pM}$ for the $7 \mathrm{D} 12^{\mathrm{PS}}$ control (Figure 4A). This indicates that micelles were formed already at a $\mathrm{VHH}$ concentration as low as $82.7 \mathrm{pM}$, corresponding to an $\mathrm{ELP}^{\mathrm{DB}}$ concentration of $4.1 \mathrm{nM}$. No toxicity was observed toward E98 cells, proving that 7D12mediated binding and uptake is necessary for toxicity. Control micelles composed of $2 \% \mathrm{Fc}^{\mathrm{FL}}-\mathrm{ELP}^{\mathrm{DB}}$ and $98 \%$ PS-ELP $\mathrm{PB}^{\mathrm{DB}}$ showed no light-dependent toxicity upon illumination of either A431 or E98 cells. Importantly, no dark toxicity of either particle was found (Figure 4B). The cell-killing efficiency of 7D12-ELP ${ }^{\mathrm{DB}}$ particles preincubated in human serum at $37^{\circ} \mathrm{C}$ for up to $4 \mathrm{~h}$, was surprisingly increased compared to particles diluted in DMEM/10\%FCS (Figure S8), indicating that particles are stable and therapeutically active in $100 \%$ serum.

The cell-specificity of the particles was further confirmed by coculturing DiO-labeled A431 (green) and DiD-labeled E98 (blue) cells and performing photoimmunotherapy as described above. By staining dead cells with propidium iodide, it was observed that only EGFR expressing A431 cells died (Figure $4 \mathrm{C})$. Thus, targeted photoimmunotherapy with $7 \mathrm{D} 12^{\mathrm{FL}}-\mathrm{PS}$ $\mathrm{ELP}^{\mathrm{DB}}$ micelles is highly specific for target-expressing cells without harming neighboring target-negative cells.

The used light dose of $60 \mathrm{~J} / \mathrm{cm}^{2}$ is physiologically relevant; clinical studies reported safe use of light doses up to $125 \mathrm{~J} / \mathrm{cm}^{2}$ in, for example, nonsmall cell carcinoma in the lung and cervical cancer. ${ }^{35}$ Still, the penetration depth of near-infrared light is below $1 \mathrm{~cm}$, and therefore this treatment will often have to be combined with surgery. 
Assuming Poisson distribution, 2\% VHH-ELP ${ }^{\mathrm{DB}}$ are sufficient to ensure that $\sim 98 \%$ of all particles contain at least one targeting moiety. This leaves ample opportunities to combine several targeting groups in one particle and to further optimize their composition.

\section{CONCLUSION}

In conclusion, we have shown successful self-assembly of $\mathrm{VHH}$ $\mathrm{ELP}^{\mathrm{DB}}$ conjugates into micelles that can be used for targeted photodynamic therapy in vitro and potentially in vivo. The 24 $\mathrm{nm}$ radii of these micelles are considered excellent for nanomedicine; large enough to avoid rapid clearance from the circulation, yet small enough to extravasate and penetrate the intercellular space of tumors. The system allows implementation of multiple $\mathrm{VHHs}$ to generate multitargeted drug delivery nanoparticles. Spontaneous micelle formation required concentrations as low as $4.1 \mathrm{nM}$. Further efforts will focus on validating the in vivo stability and activity of ELP ${ }^{D B}$ nanoparticles. Combining the system with therapeutic and diagnostic molecules may result in an interesting theranostic platform.

\section{ASSOCIATED CONTENT}

\section{S Supporting Information}

The Supporting Information is available free of charge on the ACS Publications website at DOI: 10.1021/acs.biomac.7b00064.

Protein sequence data SEC-MALS data of ELP ${ }^{\mathrm{DB}}$ and $10 \%$ Fc5-ELP ${ }^{\mathrm{DB}}$ CMC determination by DLS particles stability in human serum, as determined by DLS mass spectrometry data for all modified proteins. Microscopy of A431 cells after incubation with $\mathrm{VHH}^{\mathrm{FL}}$-Alexa ${ }^{647}$ $\mathrm{ELP}^{\mathrm{DB}}$ micelles. Effectivity of PIT after prior incubation in human serum (PDF).

\section{AUTHOR INFORMATION}

\section{Corresponding Authors}

*E-mail: j.vanhest@science.ru.nl; j.c.m.v.hest@tue.nl.

*E-mail: william.leenders@radboudumc.nl.

\section{ORCID 1}

Jan C. M. van Hest: 0000-0001-7973-2404

William P. J. Leenders: 0000-0003-0066-220X

\section{Author Contributions}

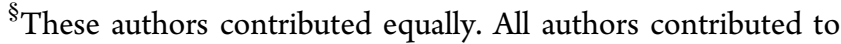
writing of the manuscript. All authors have given approval to the final version of the manuscript.

\section{Funding}

This work was supported by Radboud University, Radboudumc, and the Ministry of Education, Culture and Science (Gravitation Program 024.001.035).

\section{Notes}

The authors declare no competing financial interest.

\section{ACKNOWLEDGMENTS}

We are grateful to A. Spies and M. van Stevendaal for preliminary work on VHH-ELP conjugates.

\section{ABBREVIATIONS}

A431, cell line expressing EGFR; CBB, Coomassie Brilliant Blue; CMC, critical micelle concentration; DLS, dynamic light scattering; E98, cell line not expressing EGFR; EGFR, endothelial growth factor receptor; ELP, elastin-like peptide; $\mathrm{ELP}^{\mathrm{DB}}$, elastin-like peptide diblock copolypeptide; LCST, lower critical solution temperature; PIT, photodynamic immunotherapy; PS, photosensitizer; SEC-MALS, size-exclusion chromatography multiangle light scattering; $\mathrm{VHH}$, heavy-chain antibody fragments

\section{REFERENCES}

(1) Muyldermans, S. Nanobodies: Natural Single-Domain Antibodies. Annu. Rev. Biochem. 2013, 82, 775-797.

(2) Wesolowski, J.; Alzogaray, V.; Reyelt, J.; Unger, M.; Juarez, K.; Urrutia, M.; Cauerhff, A.; Danquah, W.; Rissiek, B.; Scheuplein, F.; Schwarz, N.; Adriouch, S.; Boyer, O.; Seman, M.; Licea, A.; Serreze, D. V.; Goldbaum, F. A.; Haag, F.; Koch-Nolte, F. Single domain antibodies: promising experimental and therapeutic tools in infection and immunity. Med. Microbiol. Immunol. 2009, 198 (3), 157-174.

(3) Muyldermans, S.; Baral, T. N.; Retarnozzo, V. C.; De Baetselier, P.; De Genst, E.; Kinne, J.; Leonhardt, H.; Magez, S.; Nguyen, V. K.; Revets, H.; Rothbauer, U.; Stijemans, B.; Tillib, S.; Wernery, U.; Wyns, L.; Hassanzadeh-Ghassabeh, G.; Saerens, D. Camelid immunoglobulins and nanobody technology. Vet. Immunol. Immunopathol. 2009, 128 (1-3), 178-183.

(4) van Driel, P. B.; Boonstra, M. C.; Slooter, M. D.; Heukers, R.; Stammes, M. A.; Snoeks, T. J.; de Bruijn, H. S.; van Diest, P. J.; Vahrmeijer, A. L.; van Bergen En Henegouwen, P. M.; van de Velde, C. J.; Lowik, C. W.; Robinson, D. J.; Oliveira, S. EGFR targeted nanobody-photosensitizer conjugates for photodynamic therapy in a pre-clinical model of head and neck cancer. J. Controlled Release 2016, 229, 93.

(5) van der Meel, R.; Oliveira, S.; Altintas, I.; Haselberg, R.; van der Veeken, J.; Roovers, R. C.; van Bergen en Henegouwen, P. M.; Storm, G.; Hennink, W. E.; Schiffelers, R. M.; Kok, R. J. Tumor-targeted Nanobullets: Anti-EGFR nanobody-liposomes loaded with anti-IGF1R kinase inhibitor for cancer treatment. J. Controlled Release 2012, 159 (2), 281-9.

(6) Arias, J. L.; Unciti-Broceta, J. D.; Maceira, J.; Del Castillo, T.; Hernandez-Quero, J.; Magez, S.; Soriano, M.; Garcia-Salcedo, J. A. Nanobody conjugated PLGA nanoparticles for active targeting of African Trypanosomiasis. J. Controlled Release 2015, 197, 190-8.

(7) Zhu, M.; Hu, Y.; Li, G.; Ou, W.; Mao, P.; Xin, S.; Wan, Y. Combining magnetic nanoparticle with biotinylated nanobodies for rapid and sensitive detection of influenza H3N2. Nanoscale Res. Lett. 2014, 9 (1), 528.

(8) Van de Broek, B.; Devoogdt, N.; D’Hollander, A.; Gijs, H. L.; Jans, K.; Lagae, L.; Muyldermans, S.; Maes, G.; Borghs, G. Specific cell targeting with nanobody conjugated branched gold nanoparticles for photothermal therapy. ACS Nano 2011, 5 (6), 4319-28.

(9) Smits, F. C. M.; Castelijns, W. W. A.; van Hest, J. C. M. Crosslinked ELP-based nanoparticles, using the strain promoted azidealkyne cycloaddition. Eur. Polym. J. 2015, 62, 386-393.

(10) Lee, T. A. T.; Cooper, A.; Apkarian, R. P.; Conticello, V. P. Thermo-reversible self-assembly of nanoparticles derived from elastinmimetic polypeptides. Adv. Mater. 2000, 12 (15), 1105.

(11) Soon, A. S. C.; Smith, M. H.; Herman, E. S.; Lyon, L. A.; Barker, T. H. Development of Self-Assembling Mixed Protein Micelles with Temperature-Modulated Avidities. Adv. Healthcare Mater. 2013, 2 (7), $1045-1055$.

(12) Urry, D. W.; Gowda, D. C.; Parker, T. M.; Luan, C. H.; Reid, M. C.; Harris, C. M.; Pattanaik, A.; Harris, R. D. Hydrophobicity Scale for Proteins Based on Inverse Temperature Transitions. Biopolymers 1992, 32 (9), 1243-1250.

(13) Li, N. K.; Quiroz, F. G.; Hall, C. K.; Chilkoti, A.; Yingling, Y. G. Molecular Description of the LCST Behavior of an Elastin-Like Polypeptide. Biomacromolecules 2014, 15 (10), 3522-3530.

(14) Urry, D. W. Physical chemistry of biological free energy transduction as demonstrated by elastic protein-based polymers. J. Phys. Chem. B 1997, 101 (51), 11007-11028. 
(15) Urry, D. W.; Trapane, T. L.; Sugano, H.; Prasad, K. U. Sequential Polypeptides of Elastin - Cyclic Conformational Correlates of the Linear Polypentapeptide. J. Am. Chem. Soc. 1981, 103 (8), 2080-2089.

(16) Gross, P. C.; Possart, W.; Zeppezauer, M. An alternative structure model for the polypentapeptide in elastin. Z. Naturforsch., C: J. Biosci. 2003, 58 (11-12), 873-878.

(17) McDaniel, J. R.; Radford, D. C.; Chilkoti, A. A unified model for de novo design of elastin-like polypeptides with tunable inverse transition temperatures. Biomacromolecules 2013, 14 (8), 2866-72.

(18) Phan, H. T.; Conrad, U. Membrane-based inverse transition cycling: an improved means for purifying plant-derived recombinant protein-elastin-like polypeptide fusions. Int. J. Mol. Sci. 2011, 12 (5), 2808-21.

(19) Pinedo-Martin, G.; Castro, E.; Martin, L.; Alonso, M.; Rodriguez-Cabello, J. C. Effect of surfactants on the self-assembly of a model elastin-like block corecombinamer: from micelles to an aqueous two-phase system. Langmuir 2014, 30 (12), 3432-40.

(20) van Eldijk, M. B.; Smits, F. C. M.; Vermue, N.; Debets, M. F.; Schoffelen, S.; van Hest, J. C. M. Synthesis and Self-Assembly of WellDefined Elastin-Like Polypeptide-Poly(ethylene glycol) Conjugates. Biomacromolecules 2014, 15 (7), 2751-2759.

(21) Floss, D. M.; Mockey, M.; Zanello, G.; Brosson, D.; Diogon, M.; Frutos, R.; Bruel, T.; Rodrigues, V.; Garzon, E.; Chevaleyre, C.; Berri, M.; Salmon, H.; Conrad, U.; Dedieu, L. Expression and immunogenicity of the mycobacterial Ag85B/ESAT-6 antigens produced in transgenic plants by elastin-like peptide fusion strategy. J. Biomed. Biotechnol. 2010, 2010, 274346.

(22) Urry, D. W.; Parker, T. M.; Reid, M. C.; Gowda, D. C. Biocompatibility of the Bioelastic Materials, Poly(Gvgvp) and Its Gamma-Irradiation Cross-Linked Matrix - Summary of Generic Biological Test-Results. J. Bioact. Compat. Polym. 1991, 6 (3), 263282.

(23) Roovers, R. C.; Vosjan, M. J.; Laeremans, T.; el Khoulati, R.; de Bruin, R. C.; Ferguson, K. M.; Verkleij, A. J.; van Dongen, G. A.; van Bergen en Henegouwen, P. M. A biparatopic anti-EGFR nanobody efficiently inhibits solid tumour growth. Int. J. Cancer 2011, 129 (8), 2013-24.

(24) Roovers, R. C.; Laeremans, T.; Huang, L.; De Taeye, S.; Verkleij, A. J.; Revets, H.; de Haard, H. J.; van Bergen en Henegouwen, P. M. Efficient inhibition of EGFR signaling and of tumour growth by antagonistic anti-EFGR Nanobodies. Cancer Immunol. Immunother. 2007, 56 (3), 303-317.

(25) Abulrob, A.; Sprong, H.; Van Bergen en Henegouwen, P.; Stanimirovic, D. The blood-brain barrier transmigrating single domain antibody: mechanisms of transport and antigenic epitopes in human brain endothelial cells. J. Neurochem. 2005, 95 (4), 1201-14.

(26) Abulrob, A.; Sprong, H.; Henegouwen, P. V. B. E.; Stanimirovic, D. The blood-brain barrier transmigrating single domain antibody: mechanisms of transport and antigenic epitopes in human brain endothelial cells. J. Neurochem. 2005, 95 (4), 1201-1214.

(27) McDaniel, J. R.; Mackay, J. A.; Quiroz, F. G.; Chilkoti, A. Recursive directional ligation by plasmid reconstruction allows rapid and seamless cloning of oligomeric genes. Biomacromolecules 2010, 11 (4), 944-52.

(28) Zhao, H.; Brown, P. H.; Schuck, P. On the distribution of protein refractive index increments. Biophys. J. 2011, 100 (9), 230917.

(29) Hirel, P. H.; Schmitter, J. M.; Dessen, P.; Fayat, G.; Blanquet, S. Extent of N-Terminal Methionine Excision from Escherichia-Coli Proteins Is Governed by the Side-Chain Length of the Penultimate Amino-Acid. Proc. Natl. Acad. Sci. U. S. A. 1989, 86 (21), 8247-8251.

(30) Liu, Y. D.; Goetze, A. M.; Bass, R. B.; Flynn, G. C. N-terminal Glutamate to Pyroglutamate Conversion in Vivo for Human IgG2 Antibodies. J. Biol. Chem. 2011, 286 (13), 11211-11217.

(31) Brewer, A. K.; Striegel, A. M. Characterizing the size, shape, and compactness of a polydisperse prolate ellipsoidal particle via quadruple-detector hydrodynamic chromatography. Analyst 2011, 136 (3), 515-519.
(32) Burchard, W. Static and Dynamic Light-Scattering from Branched Polymers and Bio-Polymers. Adv. Polym. Sci. 1983, 48, 1124.

(33) Bhunia, D.; Chowdhury, R.; Bhattacharyya, K.; Ghosh, S. Fluorescence fluctuation of an antigen-antibody complex: circular dichroism, FCS and smFRET of enhanced GFP and its antibody. Phys. Chem. Chem. Phys. 2015, 17 (38), 25250-9.

(34) Schmitz, K. R.; Bagchi, A.; Roovers, R. C.; van Bergen en Henegouwen, P. M.; Ferguson, K. M. Structural evaluation of EGFR inhibition mechanisms for nanobodies/VHH domains. Structure 2013, 21 (7), 1214-24.

(35) Keefe, K. A.; Tadir, Y.; Tromberg, B.; Berns, M.; Osann, K.; Hashad, R.; Monk, B. J. Photodynamic therapy of high-grade cervical intraepithelial neoplasia with 5-aminolevulinic acid. Lasers Surg. Med. 2002, 31 (4), 289-93. 